\title{
Using a tiered approach based on ecotoxicological techniques to assess the ecological risks of contamination in a subtropical estuarine protected area
}

\author{
B.G. Campos ${ }^{\text {a,* }}$, A.C.F. Cruz ${ }^{\text {a }}$, L.M. Buruaem ${ }^{\text {a }}$, A.P.C. Rodrigues ${ }^{b}$, W.T.V. Machado ${ }^{\text {b }}$, D.M.S. Abessa ${ }^{\text {a }}$ \\ a São Paulo State University (UNESP), Praça Infante Dom Henrique, s/n, CEP 11330-900 São Vicente, São Paulo, Brazil \\ ${ }^{\mathrm{b}}$ Fluminense Federal University (Universidade Federal Fluminense - UFF), Department of Geochemistry, CEP: 24020-141 Niterói, Rio de Janeiro, Brazil
}

\section{H I G H L I G H T S}

- Mining residues cause sediment contamination at CIP-PA estuary

- Combination of ammonia and metals was the main cause of sediment toxicity

- The AVS/SEM approach was not effective in predicting sediment toxicity

- Depositional areas had higher toxicity, metal levels and presented ecological risk

- Using several LOEs allowed the establishment of cause-effect relationships
G R A P H I C A L A B S T R A C T

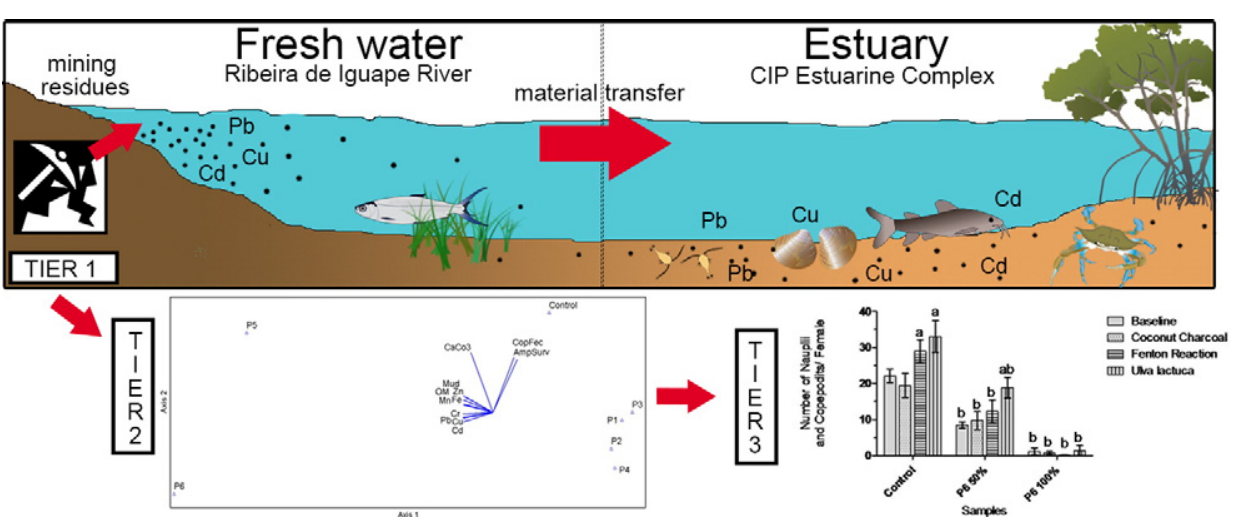

\begin{abstract}
A B S T R A C T
This study sought to assess the ecological risks of sediments from the northern portion of an estuarine protected area (Cananéia-Iguape-Peruíbe Protected Area - CIP-PA). The CIP-PA is located on the southern coast of São Paulo State, Brazil and is influenced by former mining activities along the Ribeira de Iguape River (RIR). We used a tiered approach based on multiple lines of evidence (geochemical analyses, toxicity tests, and whole sediment toxicity identification and evaluation) in order to assess environmental quality. The sediments presented a heterogeneous composition, but the samples collected close to the RIR exhibited higher concentrations of metals $(\mathrm{Cd}, \mathrm{Cr}, \mathrm{Cu}, \mathrm{Pb})$ and toxicity. Multivariate analysis showed that toxicity was associated with metals, mud, organic matter, and $\mathrm{CaCO}_{3}$ quantities. The whole-sediment toxicity identification evaluation approach indicated that ammonia and metals were responsible for sediment toxicity. Overall, we concluded that the sediments collected at depositional areas from the northern portion of the CIP-PA presented high levels of metals, which originated from former mining areas located in the upper RIR basin, and that this contamination had toxic effects on aquatic invertebrates. The tiered approach was useful for identifying the degradation of sediment quality and also for indicating the causes of toxicity. Because the CIP-PA is an important estuarine protected area that is ecologically at risk, large-scale measures are required to control the sources of contamination.
\end{abstract}

(c) 2015 Elsevier B.V. All rights reserved.

\footnotetext{
* Corresponding author.

E-mail address: brunog_campos@yahoo.com.br (B.G. Campos).
} 


\section{Introduction}

Ecological risk assessment (ERA) is a process that evaluates the likelihood that adverse ecological effects may occur or are occurring as a result of exposure to one or more stressors (USEPA, 1992). ERA has been used to understand and predict the relationships between stressors and ecological effects in order to evaluate human-induced changes that are considered ecologically undesirable (USEPA, 1998). Thus, ERA focuses on adverse effects generated or influenced by anthropogenic activity, and often involves the assessment of chemical, physical, or biological stressors or aspects.

ERA has been frequently conducted as a tiered approach. The assessment process offers more information that contributes to legislative and scientific decisions. ERA identifies stressors, their origins, and interactions between stressors and ecological variables, and it is also used to evaluate the ecological effects of the stressors identified (USEPA, 2000). Although ERA can be employed to assess the risks of a range of environmental stressors, it has been used mainly to evaluate possible risks associated with the contamination of aquatic ecosystems (Choueri et al., 2010; Chapman and Anderson, 2005).

Because environmental risks depend on the nature of the stressors and their interactions with the specific abiotic and biotic components of the ecosystem, each ERA should be conducted following specific steps. However, two major elements must be included in any ERA: characterization of effects and characterization of exposure (USEPA, 1998). When assessing ecological risks due to contamination, chemical or geochemical methods provide information on the nature and degree of contamination, while ecotoxicological methods detect the occurrence of potential biological effects (Adams et al., 1992; Petrovic and Barcelo, 2004) and provide information about both effects of and exposure to contaminants (Castro et al., 2006; Antunes et al., 2008; Chapman and Anderson, 2005).

Due to their relative simplicity, reliability, and affordability, ecotoxicological bioassays are considered one of the best ways to evaluate the effects of single and multiple contaminants and estimate their toxic potential in the environment (USEPA, 2002; Castro et al., 2006). When toxicity tests are combined with chemical analyses, they provide much more powerful information for scientific and legislative decisionmaking. However, both chemical and ecotoxicological approaches have limitations. The direct quantification of contaminants does not necessarily reflect the bioavailability to biota or the biological effects, nor does it allow for the results of interactions of multiple contaminants to be evaluated (Chapman et al., 1998; Meyer, 2002). Moreover, the range of measured contaminants is often limited due to both economic and technical restraints; thus, chemical measurements have often been restricted to the most common substances (Choueri et al., 2010). Meanwhile, ecotoxicological techniques may be influenced by confounding factors, and their application may be limited to a very small number of test protocols (with few test-species). In other words, the test conditions may not fully represent the exposure conditions in the natural environment.

In order to deal with limitations inherent to each technique alone, ecological risk assessments of sediments have used multiple lines of evidence (LOE) (Chapman et al., 2002; Choueri et al., 2010), and may incorporate new techniques to provide more information for decisionmaking processes (Chapman and Hollert, 2006).

In recent years, more advanced techniques have been developed to identify active toxicants in contaminated sediments. Of these techniques, sediment toxicity identification and evaluation (TIE) has been the most frequently adopted (Anderson et al., 2006). The TIE approach involves a suite of procedures that are designed to decrease, increase, or transform the bioavailable fractions of contaminants in order to assess their contributions to the toxicity of the sample (Araújo et al., 2013). This approach was first developed in the United States, in the 1980s to be employed within the US Clean Water Act as part of efforts to identify and remove toxic chemicals from municipal and industrial effluents discharged into the environment. In the 1990s, researchers started to use TIE to evaluate sediment interstitial waters, and later, this technique was adapted for use with whole sediments (Ho and Burgess, 2013; USEPA, 1992; USEPA, 2007). When assessing sediment quality using TIE, the three most frequently characterized classes of toxicants are nonionic organics, cationic metals, and ammonia. Sediment TIE has the potential to become a new LOE in ERA, as it provides information on the causes of toxicity (Araújo et al., 2013).

The use of multiple LOEs, including sediment TIE, provides a sensitive approach for detecting environmental disturbances and also enables estimates of environmental risks in slightly to moderately contaminated sites (Nipper et al., 1998), including marine protected areas influenced by external sources of contamination (Araújo et al., 2013).

This study used a tiered approach based on LOEs to assess the ecological risks of sediments from the northern portion of the Cananéia-Iguape-Peruíbe Protected Area (CIP-PA), an estuarine protected area that is located on the southern coast of São Paulo State in Brazil.

\section{Materials and methods}

\subsection{Study area}

The CIP-PA comprises the Cananéia-Iguape-Peruíbe (CIP) Estuarine Complex and the cities of Iguape, Cananéia, and Ilha Comprida (Fig. 1). This region is considered to be of international importance and was included within the Atlantic Rainforest Biosphere Reserve by UNESCO. Brazilian legislation has also placed the region in a protection category that was established to achieve a sustainable balance between the anthropic uses of the area's natural resources and the protection of the natural ecosystems (Moraes, 2004).

The estuarine complex is formed mainly by barrier islands and estuarine channels, which together form a complex net of water bodies. The banks of these water bodies are occupied by a set of fragile ecosystems that require protection, especially in the case of the mangroves, mudflats, and other wetlands (Schaeffer-Novelli et al., 1990). The hydrodynamic circulation of the area is influenced by tidal waves, winds, and the contributions from several rivers (Miranda et al., 1995; Myao and Harari, 1989), the most significant of which is the Ribeira de Iguape River (RIR) located in the northern portion of the CIP-PA.

The region has experienced significant changes over the past 150 years, especially after the construction of an artificial channel (known locally as Valo Grande) that connected the river to the estuary (see Fig. 1). This channel redirected approximately $70 \%$ of the RIR water flow toward the interior of the estuarine complex, thus modifying the freshwater-saltwater balance within the estuary and discharging large amounts of suspended solids in the area. Because residues from former mining activities are deposited on the riverbanks from the upper portion of the RIR (Guimarães and Sígolo, 2008a, 2008b; Kummer et al., 2011), unknown amounts of metals were continuously introduced into the river.

Since then, the RIR has been a major contributor of both nutrients and contaminants to the CIP estuarine complex (Mahiques et al., 2009), especially in the portions influenced by RIR discharges. The RIR still possesses a secondary (former) natural mouth known as the Barra do Icapara, which opens into the Atlantic Ocean near the city of Iguape and which is located at the border between the CIP-PA and the marine protected area of the southern coast (the local acronym for which is the APAMLS). As a consequence of these RIR contributions, metals have accumulated in the sediments (Aguiar et al., 2008; Mahiques et al., 2009), and some elements have been found at concentrations comparable to those observed in polluted industrial areas (Aguiar et al., 2008; Guimarães and Sígolo, 2008a, 2008b; Mahiques et al., 2009). 


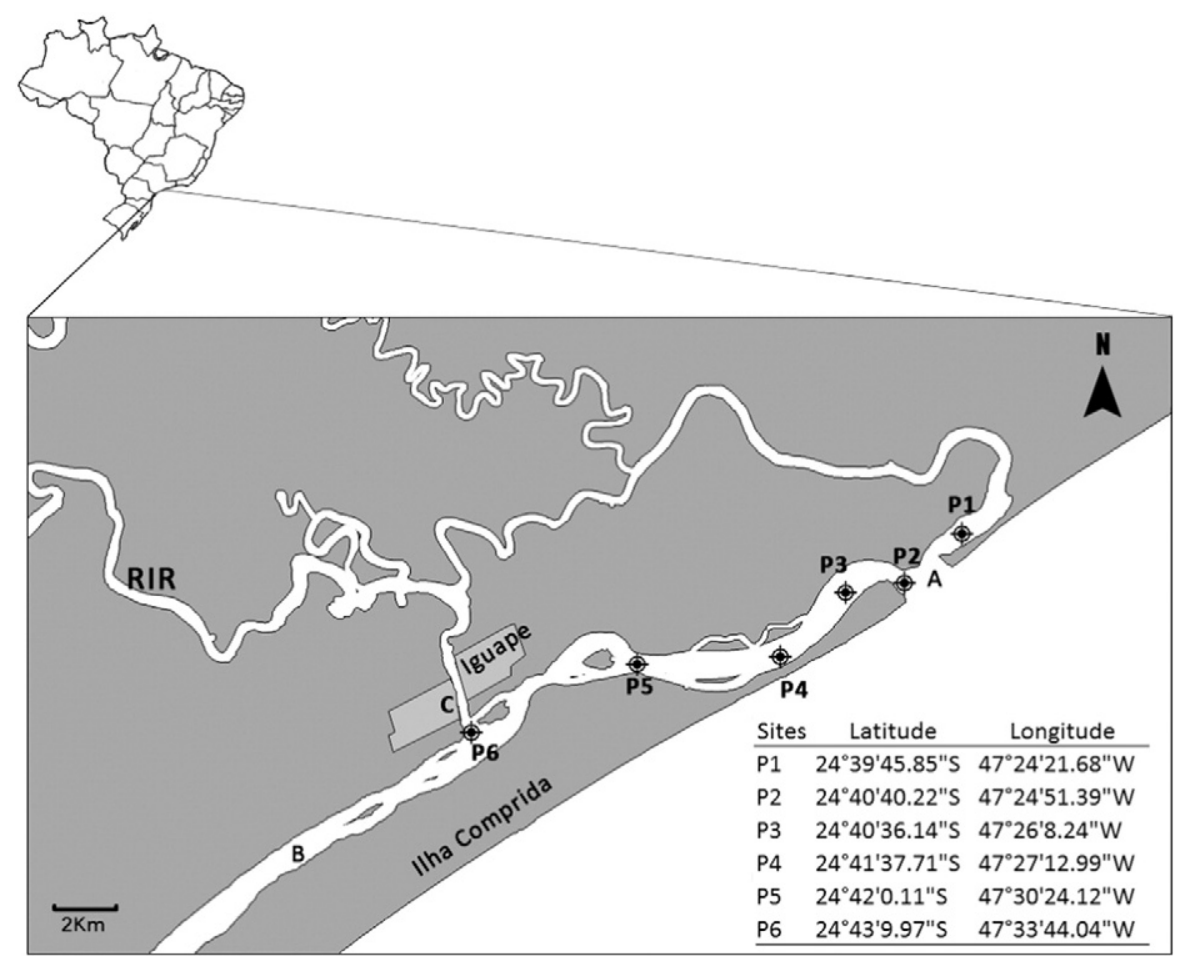

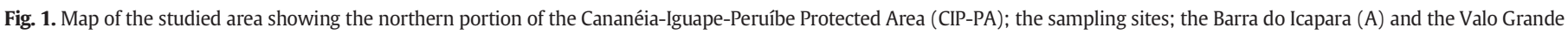
Channel (C).

\subsection{Study design}

This study was designed to employ a tiered approach in order to provide information to complement an ERA. Four tiers were used to characterize exposures to stressors and the effects associated with them (Fig. 2). The first step (Tier 0) addressed the identification of environmental stressors and was essentially a review of the literature on contamination in the RIR and the CIP-PA, as well as that on the primary sources of contaminants. The second step (Tier 1) was established to identify possible environmental alterations in sediment quality and was based on sediment toxicity tests. According to Campos et al. (2014) and Antunes et al. (2008), toxicity tests alone may provide relevant information on environmental quality, though they cannot establish causative relationships with stressors. Next, we used a combination of sediment toxicity tests with geochemical analyses (Tier 2) in order to observe possible relationships between the contaminants (stressors) and the toxicity (effects). A fourth step was then conducted to confirm which chemicals were responsible for the disturbance (Tier 3 ) in which whole-sediment TIE (phase 1) techniques were used.

\subsection{Literature review}

The first step of this investigation consisted of a broad review of the literature concerning contamination by metals in the RIR and the CIP-PA

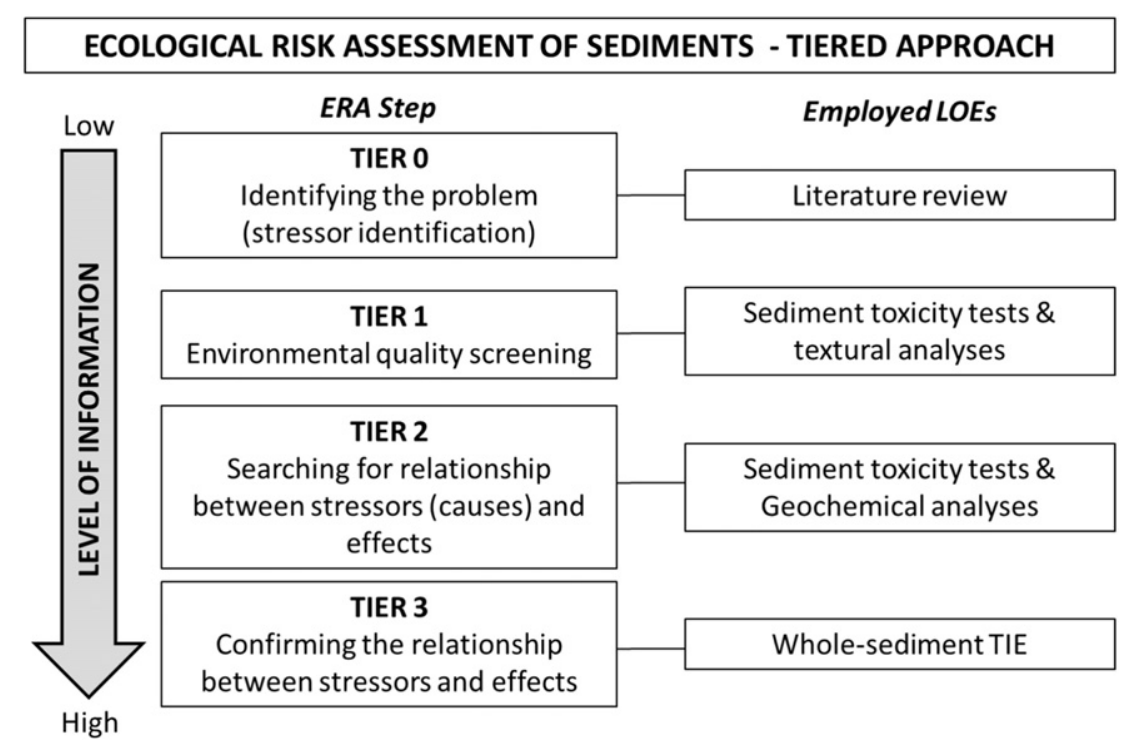

Fig. 2. Design of the ecological risk assessment to evaluate sediments from the CIP-PA based on the use of different lines of evidence organized within a tiered approach. 
(stressor identification and characterization). This review included articles, theses and dissertations, and technical reports. Its purpose was to identify the primary sources of contamination in the RIR and to understand the historical processes involved in the sources of contamination and the occurrence of other significant changes in the region. This review provided information about the fate of contaminants discharged into the RIR and their transference to estuarine and marine environments.

\subsection{Sediment sampling}

Two sampling campaigns were performed in which the sampling stations were distributed along the northern portion of the CIP-PA around the city of Iguape (Fig. 1). The sampling stations were distributed as follows: P1 was located in the natural mouth of RIR (the Barra do Icapara), while P6 was placed in the artificial mouth of the RIR (the Valo Grande Channel). Stations P2 to P5 were located between P1 and P6. The control sediment was collected further south in the CIP-PA, close to Cardoso Island in the city of Cananéia, a clean site that is not influenced by the RIR (Cruz et al., 2014). Sediments were stored in the laboratory for no longer than 2 months, as recommended by international protocols (USEPA, 2001) The first campaign was conducted in May 2012 and consisted of 5 sampling stations (P2 to P6). Sediments collected in this campaign were used in the Tier 1 phase (screening). The second sampling campaign was conducted in March 2013 and included sediments from P1 to P6; the collected sediments were used in Tier 2.

Sediment samples were collected using a $0.026 \mathrm{~m}^{2}$ stainless steel "Van Veen" grab sampler, and kept on ice in thermal boxes. In the laboratory, the aliquots for the ecotoxicological assays were stored at $4{ }^{\circ} \mathrm{C}$, while those for the geochemical analyses were stored at $-20^{\circ} \mathrm{C}$. Aliquots of sediment samples for the sediment texture analyses were separated and left to dry at $60{ }^{\circ} \mathrm{C}$ for three days before use.

\subsection{Sediment properties}

The sediment grain size distribution was analyzed using a two-step sieving process (Mudroch and Macknight, 1994): the first step consisted of wet sieving $100 \mathrm{~g}$ of previously dried sediments through a $0.062-\mathrm{mm}$ mesh to separate the silt and clay (mud) fractions; the difference between the initial and the final weights represented the mud fraction. The second step consisted of dry sieving the material retained on the $0.062-\mathrm{mm}$ mesh into a set of sieves ( $\Phi$ scale) in order to separate different classes of sands. The classification method was based on the scale established by Wentworth (1922). Calcium carbonate was determined according to the protocol described by Grant-Gross (1971), which consists of sample digestion by hydrochloric acid $(\mathrm{HCl})$ 30 volumes, followed by a new weighing and the calculation of the weight difference. Organic matter (OM) quantities in the decarbonated sediment samples were estimated using the ignition method (Luczak et al., 1997); $5 \mathrm{~g}$ of dry sediment aliquots from each sample was separated and incinerated in a muffle furnace $\left(500{ }^{\circ} \mathrm{C}\right)$ for $4 \mathrm{~h}$. Organic matter quantities were determined by calculating the difference between initial and final weights. The textural classes, $\mathrm{OM}$, and $\mathrm{CaCO}_{3}$ quantities were expressed as percentages.

\subsection{Acute sediment toxicity tests}

The sediments were tested for acute toxicity by using the 10-day test with the amphipod Tiburonella viscana (Melo and Abessa, 2002; ABNT, 2008). The preparation of each chamber test required approximately $2 \mathrm{~cm}$ of test sediment, $750 \mathrm{~mL}$ of seawater, and 10 amphipods; three replicates were prepared for each sample. During the experiments, the temperature was kept constant at $25 \pm 2{ }^{\circ} \mathrm{C}$, and the lighting and aeration were regulated as well. The animals did not receive additional food during the tests. At the end of the experiments (after 10 days), the number of survivors in each replicate was counted, and the missing animals were considered dead (Melo and Abessa, 2002). The following physical-chemical parameters of the overlying water in the test chambers were monitored and measured throughout the experiment: $\mathrm{pH}$ (digital pH meter Lutron $\mathrm{PH}-206$ ), temperature (digital thermometer), dissolved oxygen concentration (Digimed DM4P), salinity (211 hand refractometer), and ammonia concentrations (Thermo Orion 952 electrode combined with $\mathrm{pH}$ meter).

\subsection{Chronic sediment toxicity tests}

The chronic toxicity tests on the sediments were conducted using the Nitroca sp. copepod as a test-organism and following the protocol developed by Lotufo and Abessa (2002). Four replicates were prepared for each sample. Sediments were introduced into high-density $30-\mathrm{mL}$ polyethylene test chambers, forming a layer of approximately $0.4 \mathrm{~cm}$; $20 \mathrm{~mL}$ of filtered sea water were then added to each test chamber, and, finally, 10 healthy ovigerous females were introduced into each replicate. The test system was regulated to $25 \pm 2{ }^{\circ} \mathrm{C}$ for 7 days. At the end of the experiment, the contents of each test chamber were fixed through the addition of $1 \mathrm{~mL}$ formaldehyde (4\%) and Rose-Bengal dye (0.1\%). Offspring (nauplii and copepodits) and adult counts were used to determine the sub-lethal effects on reproduction.

\subsection{Chemical analyses (AVS-SEM)}

The extraction and determination of AVS and SEM concentrations were performed according to procedures described by Allen et al. (1991). Acid extraction of metals from sediments followed the technique recommended by the USEPA (Allen et al., 1991) for wet sediment samples. The extraction included digestion with hydrochloric acid $(\mathrm{HCl}$ $6 \mathrm{M}$ ) in a closed system for the generation of $\mathrm{H}_{2} \mathrm{~S}$. During this procedure, sulfides were converted into hydrogen sulfide $\left(\mathrm{H}_{2} \mathrm{~S}\right)$ by reacting with cold $\mathrm{HCl}$. The $\mathrm{H}_{2} \mathrm{~S}$ produced reacted with $\mathrm{N}$, N-dimethylphenyl-p-diamine (DMPD) in the presence of ferric chloride $\left(\mathrm{FeCl}_{3}\right)$ and was quantified using UV-visible spectrophotometry. The remaining solution after sulfide removal was filtered, and the metals $(\mathrm{Cd}, \mathrm{Cu}, \mathrm{Ni}, \mathrm{Pb}, \mathrm{Fe}, \mathrm{Mn}$ and $\mathrm{Zn}$ ) were quantified using induced coupled plasma optical emission spectrophotometry, or ICP-OES (Spectro, model Ultima 2) in duplicate samples. Finally, the SEM/AVS ratio was calculated using the molar concentrations of AVS and simultaneously extracted metals, or SEMs (Cd, $\mathrm{Cu}, \mathrm{Ni}, \mathrm{Pb}$ and $\mathrm{Zn}$ ) (Di Toro et al., 1992). Considering that the SEM/AVS model has been employed to predict the lack of toxicity in spiked and field-contaminated sediments by some specific elements that form metal sulfides more stable than $\mathrm{FeS}-\mathrm{Cd}, \mathrm{Cu}, \mathrm{Ni}, \mathrm{Pb}$ and $\mathrm{Zn}$ (Di Toro et al., 1992), we applied the model to these five metals, as supported by the theoretical basis accepted in the literature (as reviewed by Ankley et al., 1996). Ankley et al. (1996) recommended that research is also needed to establish the technical basis for SQC for elements other than the five treated by Di Toro et al. (1992), such as Hg, Ag, As and Cr. According to Di Toro et al. (1992), if the $\Sigma$ SEM/AVS ratio presents values below 1.0 , the metals are expected to be immobilized by the excess of sulfides and the sediments should therefore not be toxic. The analytical reproducibility of duplicate analysis was within $20 \%$ for metals, with the exception of some very low levels of $\mathrm{Cu}$ and $\mathrm{Zn}$ $\left(<1.0 \mathrm{mg} \cdot \mathrm{kg}^{-1}\right)$, which presented reproducibility within $50 \%$. The QA/ QC procedures also involved the use of blanks and standard reagents (PA).

\subsection{Whole-sediment TIE}

Whole sediment TIE (Phase I) was conducted based on the protocol developed by the USEPA (2007), with adaptations (Araújo et al., 2013). In this step, only the sediment from the P6 station was used, as it exhibited toxicity and the highest concentrations of metals. Two sediment dilutions were prepared with the whole sediment $(100 \%$ 
and 50\%); the P6 sediment was mixed with the control sediment (in a ratio of 50\% each) to dilute the P6 sediment. To remove ammonia, treatment with the macroalgae Ulva lactuca was employed. The macroalgae had been collected at rocky shores from clean areas and kept under constant aeration for four days with a photoperiod of 16:8 h (light: dark). Next, $0.6 \mathrm{~g}$ of the algae was placed into the testchambers $24 \mathrm{~h}$ prior to the beginning of the toxicity test in order to achieve equilibrium, and they were removed immediately before the start of the test. Fenton reagent was used to immobilize metals, at a proportion of $0.5 \mathrm{mmol}$ of $\mathrm{Fe}^{+2}$ to $50 \mathrm{mmol}$ of $\mathrm{H}_{2} \mathrm{O}_{2}$ (i.e., by adding $0.018 \mathrm{~g}$ of $\mathrm{FeSO}_{4}$ and $1.35 \mathrm{~mL}$ of $\mathrm{H}_{2} \mathrm{O}_{2}$ to each test chamber). The reaction was sustained for $24 \mathrm{~h}$ in order to achieve equilibrium, at which point the reagent was removed. The replicates were washed with dilution water to remove traces of Fenton solution that could interfere with the experiments, and the chambers were filled again with dilution water. For organic toxicants, treatment consisted of the use of coconut charcoal. The charcoal was kept in a vacuum system for $18 \mathrm{~h}$ with deionized water; $0.6 \mathrm{~g}$ of hydrated charcoal was then added to each test chamber. The organisms were added 24 h later. Finally, the sediments were tested for chronic toxicity using the copepod Nitocra sp. according to the protocol developed by Lotufo and Abessa (2002).

\subsection{Statistical analyses}

The results of the toxicity tests were first checked for normality and homoscedasticity using the Chi-square test and Bartlett's test, respectively. The results were then compared to their respective controls using Student's t-test for paired samples (Zar, 1996). Pearson correlations were applied to observe possible correlations between the toxicities and the geochemical variables. The TIE data was analyzed using a two-factor analysis of variance (ANOVA) (USEPA, 2007).

Principal components analysis (PCA) was used to explore relationships between Tier 2 variables. The data matrix used in the PCA involved the seven sampling stations (P1 to P6 and the control site) as objects and 12 variables $\left(\mathrm{Cd}, \mathrm{Cr}, \mathrm{Cu}, \mathrm{Fe}, \mathrm{Mn}, \mathrm{Pb}, \mathrm{Zn}\right.$, \% Mud, \%OM, $\mathrm{CaCO}_{3}$, amphipod survival and copepod fecundity) as descriptors. As previously mentioned, concentrations of metals were measured in duplicate, sediment properties were measured once, and ecotoxicological results were presented as means calculated from 3 to 4 replicates). As there were missing values for the AVS, we decided to not include this parameter (or the $\Sigma$ SEM/AVS ratios) in the data matrix. For those results below the detection limits, the respective values were the DLs in the dataset. Prior to the multivariate analyses, variables were $\log _{10}$-transformed and standardized to the mean values. To establish significant associations among variables, a 0.45 factor loading cutoff was used, which is higher than minimum values proposed by Comrey and Lee (1992) and used by Choueri et al. (2010). According to Hair et al. (1987), principal component loadings greater than 0.40 or less than -0.40 are considered more important, and loadings greater than 0.50 or less than -0.50 are considered very significant. Similarly, Tabachnick and Fidell (1989) suggested that loadings greater than 0.45 or less than -0.45 are fair. All statistical analyses were performed with the free PAST software.

\section{Results}

\subsection{Tier 0 - stressor identification}

The CIP estuarine complex has been considered uncontaminated by some authors (Azevedo et al., 2012); however, other studies have reported moderate to high concentrations of metals in sediments from the region (Cruz et al., 2014), especially close to the Valo Grande Channel (Aguiar et al., 2008; Mahiques et al., 2009; Saito, 2002; Guimarães and Sígolo, 2008b). In the northern portion of CIP estuarine complex, there is a consensus that the mining and metallurgical activities that took place in the upper parts of the RIR basin represent the main source of metals, and that the Plumbum Company was the main contributor of $\mathrm{Pb}, \mathrm{Cu}, \mathrm{Zn}$ and $\mathrm{Cr}$ to the system (Guimarães and Sígolo, 2008a; Piedade et al., 2014), along with a set of mines that were spread out across the region.

Mining and metallurgic activities were concentrated in the Upper Ribeira Valley, and for many decades the region was considered the largest producer of Pb of Brazil (Cunha, 2003, Di Giulio, 2006). According to Guimarães and Sígolo (2008a), nine mines operated in the region, mainly excavating $\mathrm{Pb}$ and generating metal-rich residues. During the operation of these activities ( $\approx 40$ years), the RIR basin become the final destination for metals that were carried downstream. Cassiano (2001) estimated the amount of residues from mining and stated that Plumbum alone released approximately 5.5 tons per month of toxic elements ( $\mathrm{As}, \mathrm{Cd}, \mathrm{Cu}, \mathrm{Cr}, \mathrm{Pb}$ and $\mathrm{Zn}$ ) directly into the RIR during that period. Although mining activity in the region ceased in the mid1990s, close to 177,000 tons of $\mathrm{Pb}$ mining residues (tailings, slags) were left close to the company's facilities (Piedade et al., 2014) and are still deposited on the riverbanks. They are therefore an important source of contamination due to weathering processes, floods carriage, drag by rainfall, and percolation through the groundwater, among others (Andrade et al., 2009; Barros et al., 2010; Cotta et al., 2006; Gonçalves and Carvalho, 2006; Kummer et al., 2011; Piedade et al., 2014). Abessa et al. (2014) compiled the information on the composition of the mining residues affecting RIR contamination levels and reported that both the tailings from local mines and the slags from the Plumbum plant included $\mathrm{Pb}, \mathrm{Cu}, \mathrm{Cr}, \mathrm{Zn}$ and $\mathrm{Ba}$, among other elements. Piedade et al. (2014) and Kummer et al. (2011) provided detailed information on the residues and the soils around the Plumbum factory, and showed that $\mathrm{Pb}$ concentrations reached up to $52,000 \mathrm{mg} \cdot \mathrm{kg}^{-1}$. The authors also showed that the former chimneys were a significant source of metals, and that the emitted dust particles were between $20 \%$ and $65 \% \mathrm{~Pb}$. Part of this $\mathrm{Pb}$ was considered mobile and bioavailable, with the ability to spread to waters the soil biota (Kummer et al., 2011; Duarte et al., 2012).

However, the physical and chemical characteristics of the waters from the RIR do not favor the solubilization of metals (Melo et al., 2012; Corsi and Landim, 2003; Abessa et al., 2012; Morais et al., 2013). Thus, metals are carried downstream and deposited in the suspended solids (Guimarães and Sígolo, 2008b). In addition to metal contamination, sewage may represent an important source of contamination: only $48 \%$ of Iguape households are integrated into the municipal system for sewage collection, treatment and disposal (Morais and Abessa, 2014).

In summary, metals (especially $\mathrm{Pb}$ ) constitute contaminants of interest in the CIP-PA. They originated in mining and metallurgical activities located in the upper RIR basin. They are still carried into this estuarine complex today, and they are largely adsorbed by the suspended fine particles.

Table 1

Composition of the sediments from the CIP-PA and results of the acute and chronic sediments toxicity test using Tiburonella viscana and Nitocra sp., respectively. Asterisks $\left({ }^{*}\right)$ indicate significant differences $(\mathrm{p}<0.05)$.

\begin{tabular}{llrllll}
\hline Station & $\begin{array}{l}\text { Sand } \\
(\%)\end{array}$ & \multicolumn{1}{c}{$\begin{array}{l}\text { Mud } \\
(\%)\end{array}$} & $\begin{array}{l}\mathrm{OM} \\
(\%)\end{array}$ & $\begin{array}{l}\mathrm{CaCO}_{3} \\
(\%)\end{array}$ & $\begin{array}{l}\text { Fecundity } \\
\text { (Nitocra sp.) }\end{array}$ & $\begin{array}{l}\text { Survival }(T . \\
\text { viscana) }(\%)\end{array}$ \\
\hline P2 & 98.46 & 0.78 & 0.04 & 0.71 & $26.8 \pm 6.4$ & $73.3 \pm 1.2$ \\
P3 & 43.88 & 50.03 & 1.11 & 5.00 & $21.5 \pm 1.4$ & $\mathbf{2 6 . 6} \pm \mathbf{2 5 . 0 *}$ \\
P4 & 98.40 & 0.76 & 0.04 & 0.78 & $25.8 \pm 2.2$ & $\mathbf{2 6 . 6} \pm \mathbf{2 5 . 0 ^ { * }}$ \\
P5 & 2.02 & 88.43 & 0.14 & 9.96 & $\mathbf{1 2 . 6}^{*} \pm \mathbf{1 . 7}^{*}$ & $70.0 \pm 10.0$ \\
P6 & 7.73 & 85.43 & 1.04 & 7.34 & $\mathbf{1 2 . 2} \pm \mathbf{1 . 3}^{*}$ & $\mathbf{1 6 . 0} \pm \mathbf{6 . 0}^{*}$ \\
Control & 79.42 & 7.62 & 5.33 & 7.64 & $27.6 \pm 1.2$ & $81.1 \pm 6.0$ \\
\hline
\end{tabular}


Table 2

Amounts of organic matter $(\mathrm{OM})$, calcium carbonate $\left(\mathrm{CaCO}_{3}\right)$, mud, and sand (in dry weight) in sediments from the CIP-PA.

\begin{tabular}{lllcc}
\hline Sample & $\mathrm{OM}(\%)$ & $\mathrm{CaCO}_{3}(\%)$ & Mud $(\%)$ & Sand $(\%)$ \\
\hline P1 & 0.38 & 1.24 & 0.03 & 98.35 \\
P2 & 0.42 & 1.20 & 1.33 & 97.06 \\
P3 & 0.26 & 1.35 & 2.39 & 96.00 \\
P4 & 0.21 & 0.85 & 0.77 & 98.17 \\
P5 & 6.45 & 8.21 & 85.00 & 0.35 \\
P6 & 9.44 & 5.94 & 74.93 & 9.68 \\
Control & 5.33 & 7.62 & 19.87 & 67.18 \\
\hline
\end{tabular}

\subsection{Tier 1 - screening for environmental quality}

The sediment sample compositions were found to be heterogeneous (Table 1): sediments from P5 and P6 were muddy and rich in $\mathrm{CaCO}_{3}$, while samples from P2 and P4 were predominantly sandy; the sample from P3 was composed of sandy mud. The levels of organic matter in the sediments were low, though relatively higher values were found at P3 and P6. In terms of toxicity (Table 1), samples from P3, P4, and P6 were considered acutely toxic $(p<0.05)$, whereas those from P5 and P6 exhibited chronic toxicity for Nitocra sp. $(\mathrm{p}<0.0001)$. Chronic toxicity was found to be correlated with mud $(\mathrm{r}=0.98, \mathrm{p}<0.05)$ and $\mathrm{CaCO}_{3}(\mathrm{r}=0.95, \mathrm{p}<0.05)$, whereas acute toxicity was not found to be significantly correlated with the sediment properties measured. These results indicate the possibility that environmental disturbance is the cause of sediment toxicity, especially in the region around P6 (at the mouth of the Valo Grande Channel).

\subsection{Tier 2 - relationships between stressors and effects}

Because the results from the first survey provided evidence of environmental disturbance, a second survey was conducted (see Table 2). In this campaign, the sediments from P1, P2, P3, and P4 were mainly sandy (predominance of fine and very fine sands) with low concentrations of organic matter (between $0.21 \%$ and $0.42 \%$ ). The sediments from P5 and P6 were muddy, with higher concentrations of organic matter (OM values between $6.45 \%$ and $9.44 \%$ ). The calcium carbonate quantities in the samples ranged from $0.03 \%$ to $8.21 \%$, with the highest values observed in sediments from P5 and P6. In comparison to the previous campaign, sediments from P3 exhibited changes in texture, and the OM quantities were higher at P5 and P6. Reasons for the sediment texture alteration in P3 probably are related to seasonal phenomena which alter the sedimentation within the estuary, as waves and currents generated by storms, and floodings on the RIR. However, further studies should conducted to explain the influences of the river regime and climatic conditions on the distribution of sediments within the CIP-PA.

The sediments with the highest concentrations of metals were: P6 $>$ P5 > P2 > P1 > Control > P3 > P4 (Table 3). Samples from P5 and P6 presented much higher concentrations of the majority of the elements analyzed. When compared to the control sediment, samples from P5 and P6 contained high amounts of $\mathrm{Cd}, \mathrm{Cr}, \mathrm{Cu}, \mathrm{Fe}, \mathrm{Mn}, \mathrm{Pb}$, and $\mathrm{Zn}$. Table 3 shows the results of the AVS-SEM approach. It is important to highlight the sample from P2, which exhibited a LSEM/AVS ratio higher than 1 (1.38), as well as the sample from P6 for which the ¿SEM/AVS ratio (0.98) was close to the threshold for toxicity prediction. The sediments from P1 and P5 did not generate results because the amounts of sulfides in the sample were below the analytical detection limits. The samples from P3, P4, and P6 and the control all exhibited excess amounts of AVS; thus, toxicity would not be expected in these samples.

During the acute toxicity test, physical and chemical parameters of the overlying waters in the test chamber were within the acceptable range (see supplementary material) reported by Melo and Abessa (2002). Organisms exposed to the control sediment exhibited high survival rates, as did those exposed to sediments from P1, P2, P3, P4, and P5 (Fig. 3A). Sediment from P6 induced 100\% mortality in the organisms exposed to it and was considered acutely toxic $(\mathrm{p}<0.0001)$.

In the chronic sediment toxicity test, the physical-chemical parameters recorded showed that the salinities ranged between 16 and 18 , that $\mathrm{pH}$ ranged from 7.04 to 8.12 , and that the dissolved oxygen levels ranged between 3.66 and $5.36 \mathrm{mg} \cdot \mathrm{L}^{-1}$. The sediments from the $\mathrm{P} 4$, P5, and P6 sites were toxic ( $<<0.05$ ) (Fig. 3B). The fecundity rates of Nitocra sp. in the chronic sediment toxicity test were negatively correlated with the concentrations of $\mathrm{Cu}(\mathrm{r}=-0.88 ; \mathrm{p}=0.017), \mathrm{Cd}$ $(\mathrm{r}=-0.91 ; \mathrm{p}=0.013), \mathrm{Pb}(\mathrm{r}=-0.89 ; \mathrm{p}=0.021)$, and $\mathrm{Zn}$ $(\mathrm{r}=-0.86 ; \mathrm{p}=0.029)$, results which suggest that chronic toxicity could be influenced by the concentrations of metals.

The PCA showed that the first two axes explained more than $94 \%$ of the variances (Table 4). The first axis showed associations among most of the metals, OM, muds (e.g. silt and clay particles), $\mathrm{CaCO}_{3}$, and the toxicities (negative correlations with amphipod survival and copepods fecundity). These results reinforce the probable relationships between muds, metals, and the negative effects on biota. The second axis linked together the toxicities and the amount of $\mathrm{CaCO}_{3}$. This analysis also found P5 and P6, with their high amounts of mud, metals, $\mathrm{OM}, \mathrm{CaCO}_{3}$, and toxicity, to be distinct from the control sediment (lower levels of metals, higher levels of $\mathrm{OM}, \mathrm{CaCO}_{3}$, and fines) and from P1, P2, P3 and P4 (sandy sediments, low levels of metals, moderate to higher levels of $\mathrm{OM}$, fines, and $\mathrm{CaCO}_{3}$ ); these results are detailed in Fig. 4 .

\subsection{Tier 3 - confirmation phase (whole-sediment TIE)}

When the whole-sediment TIE approach was used, the treatments were found not to be effective in removing the toxicity of the undiluted sediment samples (Fig. 5) compared to their respective controls. However, when the diluted sediment (50\% dilution) was tested, the $U$. lactuca treatment produced a significant decrease in toxicity $(\mathrm{p}<$ 0.05 ). The Fenton reagent produced a non-significant reduction in toxicity (about $20 \%$ reduction). The treatments with $U$. lactuca and Fenton reagent caused significant increases in fecundity rates in the control sediments as well $(\mathrm{p}<0.05)$. In fact, levels of ammonia in the baseline sample ranged between 3.5 and $6.5 \mathrm{mg} \cdot \mathrm{L}^{-1}$, which are

Table 3

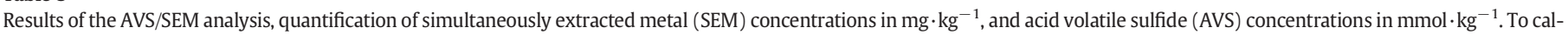
culate the $\sum \mathrm{SEM} / \mathrm{AVS}$, only $\mathrm{Cd}, \mathrm{Cu}, \mathrm{Ni}, \mathrm{Pb}$, and $\mathrm{Cr}$ were used.

\begin{tabular}{|c|c|c|c|c|c|c|c|c|c|}
\hline Sample & $\begin{array}{l}\text { AVS } \\
\left(\mathrm{mmol} \cdot \mathrm{kg}^{-1}\right)\end{array}$ & $\begin{array}{l}\mathrm{Cd} \\
\left(\mathrm{mg} \cdot \mathrm{kg}^{-1}\right)\end{array}$ & $\begin{array}{l}\mathrm{Cu} \\
\left(\mathrm{mg} \cdot \mathrm{kg}^{-1}\right)\end{array}$ & $\begin{array}{l}\mathrm{Fe} \\
\left(\mathrm{mg} \cdot \mathrm{kg}^{-1}\right)\end{array}$ & $\begin{array}{l}\mathrm{Ni} \\
\left(\mathrm{mg} \cdot \mathrm{kg}^{-1}\right)\end{array}$ & $\begin{array}{l}\mathrm{Pb} \\
\left(\mathrm{mg} \cdot \mathrm{kg}^{-1}\right)\end{array}$ & $\begin{array}{l}\mathrm{Zn} \\
\left(\mathrm{mg} \cdot \mathrm{kg}^{-1}\right)\end{array}$ & $\begin{array}{l}\mathrm{Cr} \\
\left(\mathrm{mg} \cdot \mathrm{kg}^{-1}\right)\end{array}$ & ¿SEM/AVS \\
\hline P1 & ND & $<0.01$ & 0.76 & 1558.23 & $<0.01$ & 2.14 & $<0.04$ & 0.76 & ND \\
\hline P2 & 0.049 & $<0.01$ & 0.45 & 925.13 & $<0.01$ & 0.74 & 3.76 & 0.46 & 1.38 \\
\hline P3 & 0.045 & $<0.01$ & 0.17 & 629.78 & $<0.01$ & 0.82 & 0.77 & 0.36 & 0.41 \\
\hline P4 & 0.012 & $<0.01$ & 0.16 & 589.16 & $<0.01$ & 0.89 & $<0.04$ & 0.32 & 0.65 \\
\hline P5 & ND & 0.13 & 9.83 & $16,217.97$ & $<0.01$ & 29.04 & 31.16 & 7.80 & ND \\
\hline P6 & 0.87 & 0.16 & 10.95 & $15,200.87$ & $<0.01$ & 33.41 & 33.57 & 9.13 & 0.98 \\
\hline Control & 1.03 & $<0.01$ & 0.16 & 2460.77 & $<0.01$ & 1.83 & 11.62 & 1.30 & 0.64 \\
\hline
\end{tabular}

ND: not detectable (values below detection limits). 
A

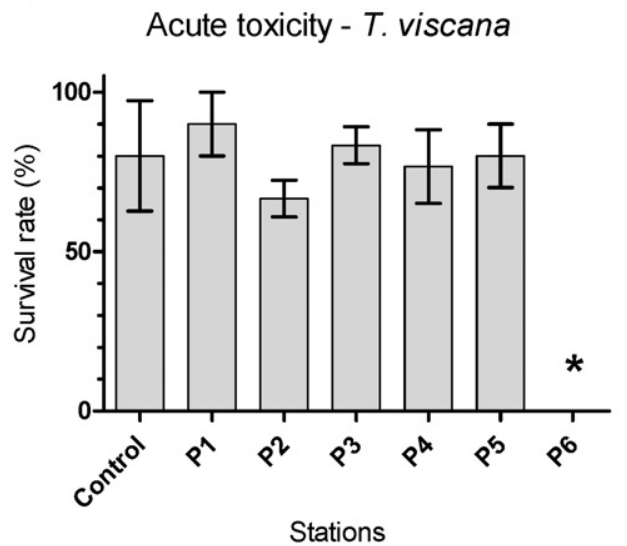

B

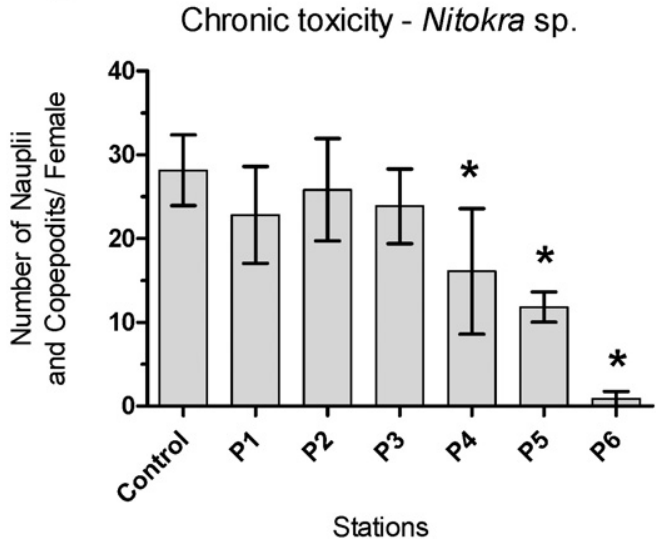

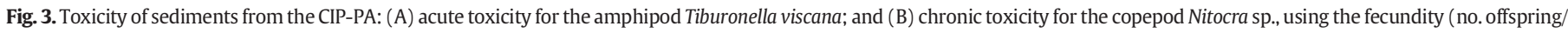
females) as the endpoint. Asterisks $\left({ }^{*}\right)$ indicate significant difference from the control $(p<0.05)$.

considered toxic to marine invertebrates (Araújo et al., 2013; Lee et al., 2000). Treated samples with $U$. lactuca presented reduced concentrations of ammonia $\left(<2.0 \mathrm{mg} \cdot \mathrm{L}^{-1}\right)$. The results of the whole-sediment TIE suggest that ammonia and metals were responsible for sediment toxicity.

\section{Discussion}

As previously mentioned, the literature indicates that mining activities that were once performed in the upper RIR are still the main source of metals that reach the CIP-PA (Mahiques et al., 2009; Saito, 2002; Guimarães and Sígolo, 2008b; Abessa et al., 2014; Morais et al., 2013). It has also been established that metals that are introduced into the system are associated with suspended fine particles (Guimarães and Sígolo, 2008b), especially through the Valo Grande Channel (Schaeffer-Novelli et al., 1990; Tessler, 1988; Saito, 2002). Fine sediment particles (e.g. clays and silts) are known for having a higher electro-chemical affinity to metals, and thus for favoring the processes of sorption, complexation and co-precipitation between contaminants and the sediment (Moore et al., 1989). In aquatic environments, metals usually tend to sink to the bottom and accumulate in the sediments (Tam and Wong, 2000), and the concentrations are often greater in fine sediments than they are in coarse sediments.

In our investigation, sediments collected close to the Valo Grande Channel were finer and presented higher concentrations of metals, results which indicate that these areas favor the precipitation of metal-enriched particles. Sediments from these areas were also found to be toxic to invertebrates, and these toxicity levels were found to be associated with the contamination. Thus, Tier 1 was able to identify the presence of environmental disturbance in the area studied, though the lack of chemical data made the conclusive establishment of causeeffect relationships impossible. Toxicity tests have been used as a first tier in ecological risk assessments of other contaminated sediments (Castro et al., 2006), since they provide a rapid and integrated measure of the toxicological significance of sediment-bound contamination (Long et al., 2001; MacDonald et al., 1992). Thus, the toxicity tests alone suggested that environmental quality was negatively affected by contamination in the CIP Estuarine System.

Because toxicity tests cannot indicate the causes of toxicity, Tier 2 was employed so that geochemical and ecotoxicological analyses could be performed. Acute toxicity was observed only in sediments from P6 (Valo Grande), whereas chronic toxicity occurred in sediments from P4, P5, and P6, with a decreasing gradient from P6 (Valo Grande) toward the sea. This gradient was also accompanied by gradients of chemical contamination and sediment texture, since sediments from P6 and P5 were muddy and presented much higher concentrations of metals. When compared to other coastal regions of Brazil, the concentrations of metals in sediments from the CIP-PA were lower than those reported in heavily contaminated areas, such as the Santos Estuarine System (Luiz-Silva et al., 2006), the Guanabara Bay (except for $\mathrm{Pb}$ ) (Neto et al., 2006), and the Todos os Santos Bay (except Pb) (Krull et al., 2014). However, CIP-PA contamination levels were above those found in the Paraguaçu Estuary (Barros et al., 2008) and Camamu Bay (Hatje et al., 2008).

The exploratory analysis clearly indicated associations among metals, muddy particles, organic matter, and toxicities. The results of the analysis suggest that metals were linked to the toxicity levels observed. These findings corroborate the other studies that observed associations between fine sediment particles and metals (Abessa et al., 2005; Lacerda et al., 2007; Liu et al., 2003), and were expected for the Valo Grande Channel vicinities (Guimarães and Sígolo, 2008b; Morais et al., 2013). In fact, this region has been reported as contaminated by metals since the 1980s (Eysink et al., 1988). Some authors have reported that areas under influence of mining activities present environmental fragilities or sediment contamination (Salomons, 1994; Cesar et al., 2004; Fialkowski et al., 2003; Angelo et al., 2007; Karbassi et al., 2008; Yau and Gray, 2005). Meanwhile, Besser et al. (2009) have found that chronic toxicity can occur even when $\mathrm{Pb}$ concentrations are below reference values.

On the other hand, the AVS/SEM approach was inconclusive for 2 samples (P1 and P5). For the others, the low ¿SEM/AVS values (generally $<1.0$ ) suggested that most of the sediment samples would not expected to be toxic due to the excess of AVS in relation of SEM.

Table 4

PCA results regarding sediment properties, chemical analyses, and toxicities in samples from the CIP-PA, São Paulo, Brazil (AmpSurv: amphipod survival rate; CopFec: copepod fecundity).

\begin{tabular}{lrr}
\hline & PC1 & \multicolumn{1}{c}{ PC2 } \\
\hline Eigenvalues & 8.95 & 1.05 \\
Variances (\%) & 84.24 & 9.88 \\
Cumulative Vars (\%) & 84.24 & 94.13 \\
$\mathrm{Cd}$ & -0.96 & -0.20 \\
$\mathrm{Cr}$ & -0.99 & -0.02 \\
$\mathrm{Cu}$ & -0.94 & -0.17 \\
$\mathrm{Fe}$ & -0.98 & 0.10 \\
$\mathrm{Mn}$ & -0.97 & 0.10 \\
$\mathrm{~Pb}$ & -0.97 & -0.08 \\
$\mathrm{Zn}$ & -0.92 & 0.26 \\
$\mathrm{AmpSurv}$ & 0.70 & 0.61 \\
$\mathrm{CopFec}$ & 0.76 & 0.63 \\
$\mathrm{OM}$ & -0.93 & 0.25 \\
$\mathrm{CaCO}$ & & 0.49 \\
$\mathrm{Mud}$ & -0.84 & 0.25
\end{tabular}




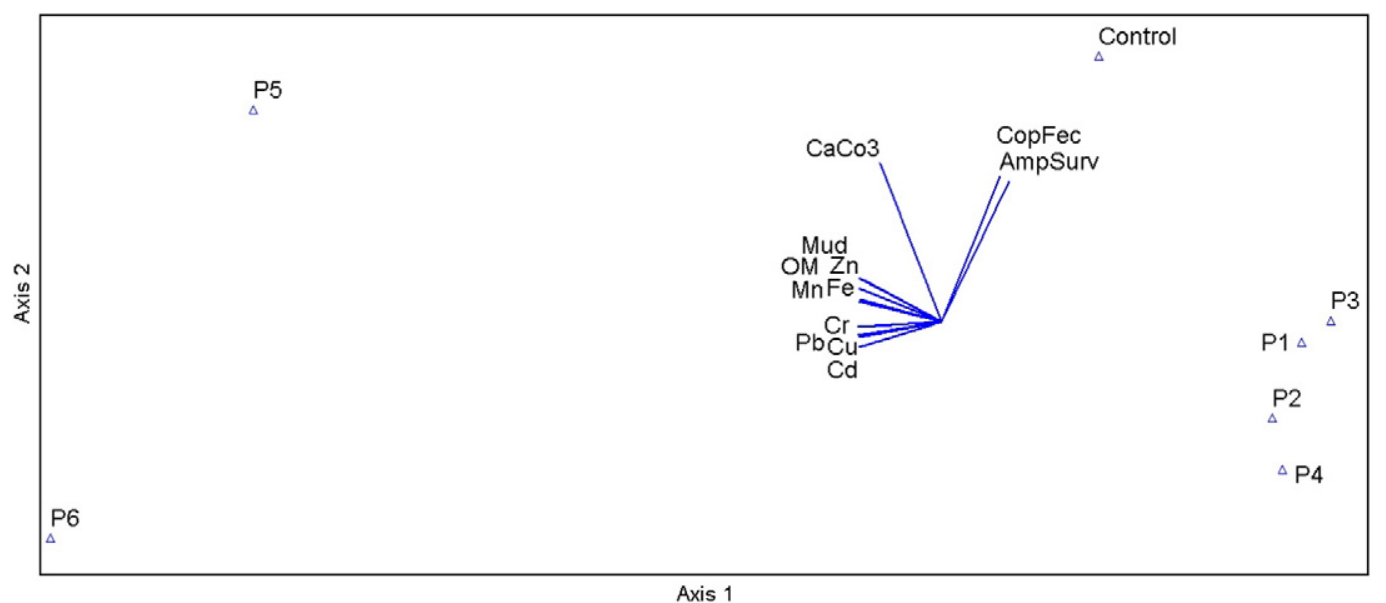

Fig. 4. Bi-dimensional ordination of PCA results using geochemical and ecotoxicological data obtained from sediments from the CIP-PA $(P C 1 \times P C 2)$.

According to Di Toro et al. (1992), the higher the $\Sigma$ SEM/AVS value the greater the potential toxicity of the sample. Thus, because toxicity was observed in some samples, the AVS-SEM approach was not completely consistent with the toxicity results. This phenomenon may be due to the fact that the AVS-SEM analysis considers the bioavailable fraction of metals to be composed only of elements dissolved in the interstitial water; the fraction adsorbed by particles would not be bioavailable. However, as shown in studies on Nitocra lacustris and Nitocra spinipes (Decho and Fleeger, 1988), benthic copepods ingest sediment particles, diatoms, and bacteria; thus, the ingestion of sediment particles could activate the immobilized metal and be toxic (Araújo et al., 2013). In this sense, the AVS/SEM approach may not be effective in predicting sediment toxicity.

Because Tier 2 was not conclusive in determining the causes of toxicity, the whole-sediment TIE was employed on the sample from P6 in order to determine the causes of the toxicity (Tier 3). At 100\% dilution, TIE treatments were not effective in reducing or removing toxicity. At 50\% dilution, however, there was a significant increase in fecundity rates in the $U$. lactuca treatment. This difference indicates that ammonia is one of the causes of sediment toxicity. According to Ankley et al. (1996), ammonia is a natural compound of aquatic sediments; it comes from the natural degradation of organic nitrogen compounds by microbial activity. Thus, estuarine environments could naturally present high levels of ammonia in their sediments. In addition, the P6 sample region is near the city of Iguape, so the sewage and urban drainage may contribute to the high ammonia concentrations in these sediments. The treatment with the Fenton reaction also reduced toxicity levels (20\% reduction), suggesting that metals are also responsible for toxicity. In a recent TIE study conducted in another Brazilian marine

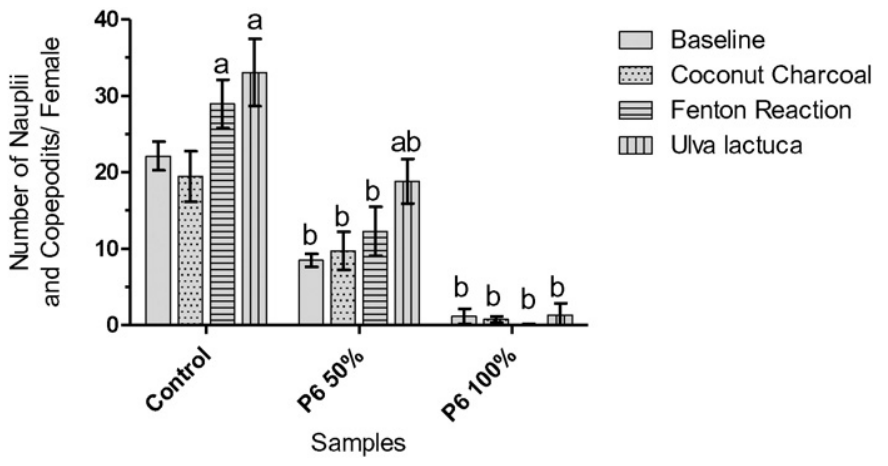

Fig. 5. Results of the whole-sediment TIE test indicating the mean fecundity rates of Nitocra sp. "a" indicates significant difference $(\mathrm{p}<0.05)$ between the treatments and their respective baselines. "b" indicates a significant difference between the treatments and their respective controls. protected area, Araújo et al. (2013) found similar results: toxicity was caused by a combination of metals and ammonia. Ankley et al. (1996) and Lee et al. (2000) each stated that ammonia can interact with other contaminants, such as metals and that this interaction produces synergic effects and increases toxicity. Thus, in naturally stressed environments such as estuaries, the effects of contaminants can be exacerbated, and toxicity among the benthic biota can be observed even when concentrations of contaminants are moderate and below legal limits. Implications from this fact reflect the need for further studies focusing the toxicity produced by the combination of ammonia with the various contaminants that can be present in coastal sediments.

Finally, this study provided information that indicates that the region of the CIP-PA under direct influence of the discharges of the RIR receives input from metals from the former mining areas located in the upper RIR basin. The metals accumulate in the sediments from depositional areas within the CIP estuarine complex and may reach toxic levels; moreover, when combined with natural compounds, such as ammonia, metals induce adverse effects on the biota in the region. The tiered approach based on ecotoxicological and chemical approaches was therefore considered suitable for determining the extent of contamination of the CIP-PA and for establishing the causes of the toxicity. The use of the tiered approach revealed the ecological risks of sediments near the Valo Grande Channel. Also, this study highlights the importance of the influence that external factors have on environmental protection areas. As Salm et al. (2000) affirmed, when the management of a protected area does not properly address the surrounding areas, protection may not be successful.

\section{Conclusion}

Sediments collected at depositional areas within the northern portion of the CIP-PA were found to be contaminated by metals that originated at former mining areas located in the upper RIR basin. The concentrations of metals found are capable of inducing toxic effects on benthic crustaceans exposed to the sediments. These effects occur largely because of the synergistic effects of the combination of metals and ammonia. The tiered approach, which included a TIE approach in Tier 3, is enough to indicate sediment contamination levels and the causes of toxicity. Therefore, it enables the estimation of the environmental risks to the region studied. Additionally, this investigation showed that, due to the presence of ammonia, sediment toxicity may occur even when contamination levels are low to moderate. This finding suggests that ammonia-rich environments may be especially vulnerable. Because the CIP is an important estuarine protected area, legal measures are required to control the contamination sources located upstream. 


\section{Acknowledgments}

We would like to thank the São Paulo State Research Foundation (FAPESP; grant \#2012/03939-3), the Brazilian National Council for Scientific and Technological Development (CNPq; grant \#479899/ 2013-4) and the Brazilian Aquatic Research Foundation (FUNDESPA) for their financial support. We would also like to thank the Institute of Oceanography of the University of São Paulo (IO-USP) for their logistics support during sediment collections and the staff from UNESP, UFF, and UFRJ for the assistance with the experiments and analyses. We thank Dr. Renato C. Cordeiro (UFF) for his help with the geochemical analyses. Dr. Lucas Buruaem thanks to FAPESP (grant \#13/15482-0, São Paulo State Research Foundation), and Dr. Abessa thanks CNPq (grants 308649/ 2011-7 and 311609/2014-7).

\section{References}

Abessa, D.M.S., Carr, R.S., Rachid, B.R.F., Sousa, E.C.P.M., Hortelani, M.A., Sarkis, J.E., 2005. Influence of a Brazilian sewage outfall on the toxicity and contamination of adjacent sediments. Mar. Pollut. Bull. 50 (8), 875-885.

Abessa, D.M.S., Morais, L.G., Perina, F.C., Davanso, M.B., Buruaem, L.M., Martins, L.M.P., Sígolo, J.B., Rodrigues, V.G.S., 2012. Toxicidade de águas e sedimentos em um rio afetado por atividades mineradoras pretéritas. Mundo Saúde. 36 (4), 610-618.

Abessa, D.M.S., Morais, L.G., Perina, F.C., Davanso, M.B., Rodrigues, V.G.S., Martins, L.M.P., Sígolo, J.B., 2014. Sediment geochemistry and climatic influences in a river influenced by former mining activities: the case of Ribeira de Iguape River, SP-PR, Brazil. Open J. Water Pollut. Treat. 1 (1), 43-53.

ABNT, AssociaçãoBrasileira de Normas Técnicas, 2008. ABNT/NBR 15638:2008. Qualidade da Água - Determinação da toxicidade aguda de sedimentos marinhos ou estuarinos com anfípodos (17 pp.)

Adams, W.J., Kimerle, R.A., Barnett Jr., J.W., 1992. Sediment quality and aquatic life assessment. Environ. Sci. Technol. 26 (10), 1865-1875.

Aguiar, V.M.C., Braga, E.S., Baptista-Neto, J.A., 2008. Heavy metal assessment in two subtropical Estuarine System in the State of São Paulo, Brazil 2008 In: Hofer, T.N. (Ed.), Marine Pollution: New Research, first ed. Nova Science Publisher, Inc. (379-397 pp., ISBN 1604562420, 9781604562422)

Allen, H.E., Fu, G., Boothman, W., Di Toro, D.M., Mahony, J.D., 1991. Determination of acid volatile sulfides and selected simultaneously extractable metals in sediment. EPA821/12-91/100. Protection Agency, Washington, DC, US Environmental.

Anderson, B., Hunt, J., Phillips, B., Tjeerdema, R., 2006. Navigating the TMDL process: sediment toxicity. 02-WSM-2. Final Report. Water Environment Research Foundation, Alexandria, VA, USA

Andrade, M.G., Melo, V.F., Gabardo, J., Souza, L.C.P., Reissmann, C.B., 2009. Metais pesados em solos de área de mineração e metalurgia de chumbo. I-Fitoextração. Braz. J. Soil Sci. 33 (6), 1879-1888.

Angelo, R.T., Cringan, M.S., Chamberlain, D.L., Stahl, A.J., Haslouer, S.G., Goodrich, C.A., 2007. Residual effects of lead and zinc mining on freshwater mussels in the Spring River Basin (Kansas, Missouri, and Oklahoma, USA). Sci. Total Environ. 384 (1-3), 467-496.

Ankley, G.T.D.M., Di Toro, D.M., Hansen, D.J., Berry, W.J., 1996. Technical basis and proposal for deriving sediment quality criteria for metals. Environ. Toxicol. Chem. 15 (12), 2056-2066.

Antunes, S.C., Castro, B.B., Pereira, R., Gonçalves, F., 2008. Contribution for tier 1 of the ecological risk assessment of Cunha Baixa uranium mine (Central Portugal): II. Soil ecotoxicological screening. Sci. Total Environ. 15 (2-3), 387-395.

Araújo, G.S., Moreira, L.B., Morais, R.D., Davanso, M.B., Garcia, T.F., Cruz, A.C.F., Abessa, D.M.S., 2013. Ecotoxicological assessment of sediments from an urban marine protected area (Xixová-Japuí State Park, SP, Brazil). Mar. Pollut. Bull. 75 (1-2), 62-68.

Azevedo, J.S., Braga, E.S., Oliveira Ribeiro, C.A., 2012. Nuclear abnormalities in erythrocytes and morphometric indexes in the catfish Cathorops spixii (Ariidae) from different sites on the Southeastern Brazilian coast. Braz. J. Oceanogr. 60 (3), 323-330.

Barros, F., Hatje, V., Figueiredo, M.B., Magalhães, W.F., Dórea, H.S., Emídio, E.S., 2008. The structure of the benthic macrofaunal assemblages and sediments characteristics of Paraguaçu estuarine system, NE, Brazil. Estuar. Coast. Shelf Sci. 78, 753-762.

Barros, Y.J., Melo, V.F., Sautter, K.D., Buschle, B., Oliveira, E.B., Azevedo, J.C.R., Souza, L.C.P., Kummer, L., 2010. Indicadores de qualidade de solos de área de mineração e metalurgia de chumbo: II-mesofauna e plantas. Braz. J. Soil Sci. 34 (4), 1413-1426.

Besser, J.M., Brumbaugh, W.G., Allert, A.L., Poulton, B.C., Schmitt, C.J., Ingersoll, C.G., 2009. Ecological impacts of lead mining on Ozark streams: toxicity of sediment and pore water. Ecotoxicol. Environ. Saf. 72 (2), 516-526.

Campos, B.G., Abessa, D.M.S., Lopes, M.C., Silva, N.J.R., 2014. Avaliação ecotoxicológica em piscicultura no Parque Estadual da Serra do Mar (SP), Núcleo Itariru. Mundo Saúde 38 (1), 98-104

Cassiano, A.M., 2001. Estudo da contaminação por metais na bacia do Rio Ribeira de Iguape (SP-PR): Estratégias para a remediação da área de disposição de rejeitos da mina do Rocha. Escola de Engenharia de São Carlos, Universidade de São Paulo, São Carlos, Tese de Doutorado (159 pp.).

Castro, H., Ramalheira, F., Quintino, V., Rodrigues, A.M., 2006. Amphipod acute and chronic sediment toxicity assessment in estuarine environmental monitoring: an example from Ria de Aveiro, NW Portugal. Mar. Pollut. Bull. 53 (1-4), 91-99.
Cesar, A., Marín, A., Marín-Guirao, L., Vita, A., 2004. Amphipod and sea urchin tests to assess of Mediterranean sediments: the case of Pórtman Bay. Sci. Mar. 68 (S1) 205-2013.

Chapman, P.M., Anderson, J., 2005. A decision-making framework for sediment contamination. Integr. Environ. Assess. Manag. 1 (5), 163-173.

Chapman, P.M., Hollert, H., 2006. Should the sediment quality triad become a tetrad, a pentad, or possibly even a hexad? J. Soil Sediments 6 (1), 4-8.

Chapman, P.M., McDonald, B.G., Lawrence, G.S., 2002. Weight-of-evidence issues and frameworks for sediment quality (and other) assessments. Hum. Ecol. Risk. Assess. 8 (7), 1489-1515.

Chapman, P.M., Wang, F., Janssen, C., Persoone, G., Allen, H.E., 1998. Ecotoxicology of metals in aquatic sediments: binding and release, bioavailability, risk assessment and remediation. Can. J. Fish Aquat. Sci. 55 (10), 2221-2243.

Choueri, R.N., Torres, R.J., Morais, R.D., Abessa, D.M.S., Pereira, C.D.S., Cesar, A., Nascimento, M.R.L., Mozeto, A.A., Riba, I., Delvalls, T.A., 2010. Harmonised framework for ecological risk assessment of sediments from ports and estuarine zones of North and South Atlantic. Ecotoxicology 19 (4), 678-696.

Comrey, A.L., Lee, H.B., 1992. A First Course in Factor Analysis. second ed. L. Erlbaum Associates, Hillsdale (488 pp.).

Corsi, A.C., Landim, P.M.B., 2003. Chumbo, Zinco e Cobre em sedimentos de corrente nos Ribeirões Grande, Perau e Canoas, e Córrego Barrinha no município de Adrianopólis (Vale do Ribeira, PR). Geociências 22, 49-61.

Cotta, J.A.O.C., Rezende, M.O.O., Piovani, M.R., 2006. Avaliação do teor de metais em sedimento do rio Betari no Parque Estadual Turístico do Alto do Ribeira - Petar, São Paulo, Brasil. Quím. Nova 29 (1), 40-45.

Cruz, A.C.F., Davanso, M.B., Araújo, G.S., Buruaem, L.M., Santaella, S.T., Morais, R.D., Abessa, D.M.S., 2014. Cumulative influences of a small city and former mining activities on the sediment quality of a subtropical estuarine protected area. Environ. Monit. Assess. 186 (11), 7035-7046.

Cunha, F.G., 2003. Contaminação humana e ambiental por chumbo no Vale do Ribeira, nos Estados de São Paulo e Paraná. Tese de Doutorado, Instituto de Geociências, Universidade Estadual de Campinas, São Paulo, Brasil, Brasil.

Decho, A.W., Fleeger, J.W., 1988. Ontogenetic feeding shifts in the meiobenthic harpacticoid copepod Nitocra lacustris. Mar. Biol. 97 (2), 191-197.

Di Giulio, G.M., 2006. Divulgação Cientifica e comunicação de risco - um olhar sobre Adrianópolis. Dissertação de Mestrado, Instituto de Geociências, Universidade Estadual de Campinas, São Paulo, Brasil, Vale do Ribeira.

Di Toro, D.M., Mahony, J.D., Hansen, D.J., Scott, K.J., Carlson, A.R., Ankley, G.T., 1992. Acid volatile sulfide predicts the acute toxicity of cadmium and nickel in sediments. Environ. Sci. Technol. 26 (1), 96-101.

Duarte, A.P., Melo, V.F., Brown, G.G., Pauletti, V., 2012. Changes in the forms of lead and manganese in soils by passage through the gut of the tropical endogeic earthworm (Pontoscolex corethrurus). Eur. J. Soil Biol. 53, 32-39.

Eysink, G.G.J., Pádua, H.B., Piva-Bertoletti, S.A.E., Martins, M.C., Pereira, D.N., 1988. Metais pesados no Vale do Ribeira e Iguape-Cananéia. Ambiente 2 (1), 6-13.

Fialkowski, W., Klonowska-Olejnika, M., Smith, B.D., Rainbow, P.S., 2003. Mayfly larvae (Baetis rhodani and B. vernus) as biomonitors of trace metal pollution in streams of a catchment draining a zinc and lead mining area of Upper Silesia, Poland. Environ. Pollut. 121 (2), 253-367.

Gonçalves, G.M., Carvalho, C.E.V., 2006. Particulate heavy metal dynamics in a tropical estuary under distinct river discharge and tidal regimes, southeastern, Brazil. J. Coast. Res. Spec. Issue 39, 1032-1035.

Grant-Gross, M., 1971. Carbon Determination. In: Carver, R.E. (Ed.), Procedures in Sedimentary Petrology, first ed. Wiley Interscience, New York (285-312 pp.).

Guimarães, V., Sígolo, J.B., 2008a. Detecção de contaminantes em espécie bioindicadora (Corbicula fluminea) - Rio Ribeira de Iguape - SP. Quím. Nova 31 (7), 1696-1698

Guimarães, V., Sígolo, J.B., 2008b. Associação de resíduos da Metalurgia com sedimentos em Suspensão - Rio Ribeira de Iguape. Rev. Inst. Geociênc. USP 8 (2), 1-10.

Hair Jr., J.E., Anderson, R.E., Tatham, R.L., 1987. Multivariate Data Analysis. second ed. NewYork, Macmillan (449 pp.).

Hatje, V., Barros, F., Magalhaes, W., Riatto, V.B., Amorim, F.N., Betânia, M., Figueredo, M.B., Spano, S., Cinaro, M., 2008. Trace metals and benthic macrofauna distribution in Camamu Bay, Brazil: sediment quality prior oil and gas exploration. Mar. Pollut. Bull. 56 (2), 363-370.

Ho, K.T., Burgess, R.M., 2013. What's causing toxicity in sediments? Results of 20 years of toxicity identification and evaluations. Environ. Toxicol. Chem. 32 (11) 2424-2432.

Karbassi, A.R., Monavari, S.M., Bidhendi, G.R.N., Nouri, J., Nematpour, K., 2008. Metal pollution assessment of sediment and water in the Shur River. Environ. Monit. Assess. 147 (1-3), 107-116.

Krull, M., Abessa, D.M.S., Hatje, V., Barros, F., 2014. Integrated assessment of metal contamination in sediments from two tropical estuaries. Ecotoxicol. Environ. Saf. 106, 195-203.

Kummer, L., Melo, V.F., Barros, Y.J., Azevedo, J.C.R., 2011. Extrações sequenciais de chumbo e zinco em solos de área de mineração e metalurgia de metais pesados. Rev. Bras. Ciênc. Solo 35 (6), 2005-2018.

Lacerda, L.D., Menezes, M.O.T. Molisani, M.M., 2007. Changes in mangrove extension at the Pacoti River estuary, CE, NE Brazil due to regional environmental changes between 1958 and 2004. Biota Neotropica. 7 (3), 67-72.

Lee, J.S., Lee, B.G., Luoma, S.N., Choi, H.J., Koh, C.H., Brown, C.L., 2000. Influence of acid volatile sulfides and metal concentrations on metal partitioning in contaminated sediments. Environ. Sci. Technol. 34, 4511-4516.

Liu, W.X., Lia, X.D., Shena, Z.G., Wang, D.C., Wai, O.W.H., Li, Y.S., 2003. Multivariate statistical study of heavy metal enrichment in sediments of the Pearl River Estuary. Environ. Pollut. 121 (3), 377-388. 
Long, E.R., Hong, C.B., Severn, C.G., 2001. Relationships between acute sediment toxicity in laboratory tests and abundance and diversity of benthic infauna in marine sediments: a review. Environ. Toxicol. Chem. 20 (1), 46-60.

Lotufo, G.R., Abessa, D.M.S., 2002. Testes de toxicidade com sedimentos total e água intersticial estuarinos utilizando copépodos bentônicos. In: Nascimento, I.A. Sousa, E.C.P.M., Nipper, M.G. (Eds.), Métodos Em EEcotoxicologia MMarinha: AAplicações NNo BBrasil, first ed. Artes Gráficas e Indústria, São Paulo, SP, pp. 51-162.

Luczak, C., Janquin, M., Kupka, A., 1997. Simple standard procedure for the routine determination of organic matter in marine sediment. Hydrobiologia 345 (1), 87-94.

Luiz-Silva, W., Matos, R.H.R., Kristosch, G.C., Machado, W., 2006. Variabilidade espacial e sazonal da concentração de elementos-traço em sedimentos do sistema estuarino de Santos-Cubatão (SP). Quím. Nova 29 (2), 256-263.

MacDonald, D.A., Matta, M.B., Field, L.J., Cairncross, C., Munn, M.D., 1992. The coastal resource coordinator's bioassessment manual. Report No. HAZMAT 93-1. National Oceanic and Atmospheric Administration, Seattle, WA (137 pp.).

Mahiques, M.M., Burone, L., Figueira, R.C.L., Lavenére-Weerley, A.A.O., Capellari, B., Rogacheski, C.E., Barroso, C.P., Santos, L.A.S., Cordero, L.M., Cossioli, M.C., 2009. Anthropogenic influences in a lagoonal environment: a multiproxy approach at the Valo Grande mouth, Cananéia-Iguape System (SE Brazil). Braz. J. Oceanogr. 57 (4), 325-337.

Melo, S.L.R., Abessa, D.M.S., Sousa, E.C.P.M., 2002. Testes de toxicidade com sedimentos marinhos utilizando anfípodos 2002 In: Nascimento, I.A., Nipper, M.G. (Eds.) Métodos Em Ecotoxicologia Marinha: Aplicações No Brasil, first ed. Artes Gráficas e Indústria, São Paulo, SP, pp. 123-178.

Melo, V.F., Andrade, M., Batista, A.H., Favaretto, N., Grassi, M.T., Campos, M.S., 2012 Chumbo e zinco em águas e sedimentos de área de mineração e metalurgia de metais. Quím. Nova 35 (1), 22-29.

Meyer, J.S., 2002. The utility if the terms "bioavailability" and "bioavailable fraction" for metals. Mar. Environ. Res. 53 (4), 417-423.

Miranda, L.B., Mesquita, A.R., Franca, C.A.S., 1995. Estudo da circulação e dos processos de mistura no extremo sul do mar de Cananéia: condições de dezembro de 1991. Bol. Inst. Oceanogr. 43 (2), 101-113.

Moore, J.N., Brook, E.J., Johns, C., 1989. Grain size partitioning of metals in contaminated, coarse-grained river floodplain sediment: Clark Fork River, Montana, USA. Environ. Geol. Water Sci. 14 (2), 107-115.

Moraes, M.B.R. 2004. Área de Proteção Ambiental - APA como agência de desenvolvimento sustentável: APA Cananéia - Iguape - Peruíbe/SP. São Paulo. Annablume, Fapesp.

Morais, L.G., Abessa, D.M.S., 2014. Using the PSR framework for coastal management: the South Coast of São Paulo as a case study. Revista da Gestão Costeira Integrada 14 (4) 625-635.

Morais, L.G., Perina, F.C., Davanso, M.B., Buruaem, L.G., Rodrigues, V.G.S., Sígolo, J.B., Abessa, D.M.S., 2013. Water and sediment ecotoxicological assessment in a river affected by former mining activities. Pan.-Am. J. Aquat. Sci. 8 (4), 327-338.

Mudroch, A., Macknight, S.D., 1994. Handbook of Techniques for Aquatic Sediments Sampling. second ed. CRC, Boca Raton (236 pp.).

Myao, S.Y., Harari, J., 1989. Estudo preliminar da maré e das correntes de maré da região estuarina de Cananéia $\left(25^{\circ} 5-48^{\circ} \mathrm{W}\right)$. Bol. Inst. Oceanogr. 37 (2), 107-123.

Neto, J.A.B., Gingele, F.X., Leipe, T., Brehme, I., 2006. Spatial distribution of heavy metals in surficial sediments from Guanabara Bay: Rio de Janeiro, Brazil. Environ. Geol. 49 (7), 1051-1063.
Nipper, M.G., Roper, D.S., Williams, E.K., Martin, M.L., Van Dam, L.F., Mills, G.N., 1998. Sediment toxicity and benthic communities in mildly contaminated sediments. Environ. Toxicol. Chem. 17 (3), 2-38.

Petrovic, M., Barcelo, D., 2004. Seeking harmonisation in assessing sediments and dredged materials. Meeting report. Trends Anal. Chem. 23 (8), 10-12.

Piedade, T.C., Melo, V.F., Souza, L.C.P., Dieckow, J., 2014. Three-dimensional data interpolation for environmental purpose: lead in contaminated soils in southern Brazil. Environ. Monit. Assess. 186 (9), 5625-5638.

Saito, R.T., 2002. Radionuclídeos (210Pb, 226Ra, 210Po e 137Cs) no Sistema Costeiro Cananéia-Iguape: Estudos ambientais (PhD Thesis) Instituto de Pesquisas Energéticas Nucleares, Universidade de São Paulo, Brasil.

Salm, R.V., Clark, J., Siirila, E., 2000. Marine and Coastal Protected Areas: A Guide for Planners and Managers. International Union for Conservation of Nature and Natural Resources, Washington DC (370 pp.).

Salomons, W., 1994. Environment impact of metal derived mining activities: processes, prediction, prevention. J. Geochem. Explor. 52 (1-2), 5-23.

Schaeffer-Novelli, Y., Mesquita, H.S.L., Cintrón-Molero, G., 1990. The Cananéia Lagoon Estuarine System, São Paulo, Brazil. Estuaries 13 (2), 193-203.

Tabachnick, B.G., Fidell, L.S., 1989. Using multivariate statistics. second ed. NewYork, Harper Collins College (746 pp.).

Tam, N.F.Y., Wong, Y.S., 2000. Spatial variation of heavy metals in surface sediments of Hong Kong mangrove swamps. Environ. Pollut. 110 (2), 195-205.

Tessler, M.G., 1988. Dinâmica sedimentar quaternária no litoral sul paulista. Instituto Oceanográfico, Universidade de São Paulo, Brasil, Tese de Doutorado.

USEPA. United States Environmental Protection Agency, 1992. Framework for Ecological Risk Assessment. Risk Assessment Forum, U.S. Environmental Protection Agency, Washington, DC (EPA/630/R-92/001).

USEPA. United States Environmental Protection Agency, 1998. Guidelines for Ecological Risk Assessment. Risk Assessment Forum, U.S. Environmental Protection Agency, Washington, DC (EPA/630/R-95/002F).

USEPA. United States Environmental Protection Agency, 2000. Stressor Identification Guidance Document. Risk Assessment Forum, U.S. Environmental Protection Agency, Washington, DC (EPA-822-B-00-025).

USEPA. United States Environmental Protection Agency, 2001. Methods for collection, storage and manipulation of sediments for chemical and toxicological analyses. Technical Manual. U.S. Environmental Protection Agency (EPA-823-B-01-002).

USEPA. United States Environmental Protection Agency, 2002. Short-term methods for estimating the chronic toxicity of effluents and receiving waters to marine and estuarine organisms. Technical Report, 3rd. ed. (U.S., EPA-821-R-02- 014).

USEPA. United States Environmental Protection Agency, 2007. Sediment Toxicity Identification Evaluation (TIE) Phases I, II, and III. Office of Research and Development, Washington (EPA/600/R-07/080).

Wentworth, C.K., 1922. A scale of grade and class terms for clastic sediments. J. Sediment. Petrol. 30, 377-379.

Yau, H., Gray, N.F., 2005. Riverine sediment metal concentrations of the Avocal/Avonmore Catchment, South-East Ireland: a baseline assessment. Biol. Environ. Proc. R. Irish Acad. 105B (2), 95-106.

Zar, J.H., 1996. Biostatistical Analysis. third ed. Prentice-Hall, New Jersey (662 pp.). 